Marwah: Jurnal Perempuan, Agama dan Jender

(p-ISSN: 1412-6095 | e-Issn: 2407-1587

Vol. 17, No. 2, 2018, Hal. 179-190

\title{
FENOMENA DOUBLE BURDEN PEREMPUAN PEMULUNG MUSLIM DALAM PENGELOLAAN EKONOMI KELUARGA
}

\author{
Suhertina, Darni \\ Universitas Islam Negeri Sultan Syarif Kasim Riau, Indonesia \\ suhertina@uin-suska.ac.id
}

\begin{abstract}
This research aims to know the phenomenon of double burden Women Scavenger Muslim families and the economy in favor of factor endowments and brominated. This research is qualitative, descriptive. Research subject was 8 women scavenge Muslim, her husband and son. It collected data through interviews, observation and documentation. Data was narrative analysis. The results showed that woman scavenger Muslims in Pekanbaru are helpful in and responsibility of the economic family. The mothers work as a scavenger whose results may help finance the rented home, school children, money power, daily living needs. Mothers who worked as a scavenger work scavenger starting at 6 in the morning until 10.00 hours and continued after 30ru noon or night. Average earnings gained $\mathrm{R} p$ 800,000 per month. As for the supporting factors that make them a scavenger because goods collected easily obtained while restricting factor i.e. weather rain, suspicion from residents because the allegations as a stealer and age.
\end{abstract}

Keywords : Double Burden, Moslem Women, Moslem Scavenger, Family Economic

\begin{abstract}
ABSTRAK
Penelitian ini bertujuan untuk mengetahui fenomena double burden Wanita Pemulung Muslim dalam Mendukung Perekonomian Keluarga serta faktor pendukung dan penghambatnya. Jenis penelitian adalah deskriptif kualitatif. Subjek penelitian 8 wanita pemulung muslim, serta suami dan anaknya. Data dikumpulkan melalui wawancara, dokumentasi dan observasi. Teknik analisa data menggunakan naratif. Hasil penelitian menunjukkan babwa wanita pemulung muslim di kota Pekanbaru sangat membantu dalam meringankam beban dan tanggungjawab suami. Para ibu memilib untuk bekerja sebagai pemulung yang hasilnya dapat membantu membiayai kontrakan rumah, sekolab anak,uang listrik, keperluan bidup sehari-hari. Ibu-ibu yang bekerja sebagai pemulung melakukan pekerjaan memulung mulai jam 06 pagi sampai jam 10.00 dan dilanjutkan setelah solat zubur atau malam hari. Rata rata penghasilan yang didapat $\mathrm{R} p 800.000$ perbulannya. Adapun faktor pendukung yang membuat mereka menjadi pemulung dikarenakan barang yang dikumpulkan mudah diperoleh sedangkan faktor penghambat yaitu cuaca hujan, rasa curiga dari warga karena tuduhan sebagai pencuri dan usia.
\end{abstract}

Kata Kunci: Double Burden, Perempuan Muslim, Pemulung Muslim, Ekonomi Keluarga 


\section{PENDAHULUAN}

Tuntutan dan kebutuhan hidup di era globalisasi ini membuat setiap keluarga berupaya bekerja keras agar dapat bertahan hidup. Dalam hal ini perempuan yang berstatus sebagai istri dan ibu bagi anak-anaknya harus mampu berperan ganda, bertanggung jawab atas urusan rumah tangga serta mencari nafkah (Dwiantini, 1995). Terjadilah ketidakadilan gender pada perempuan yang dikenal dengan istilah double burden, yang menurut kamus Keluarga Berencana (https://glosarium.org/kata/index.php/term/ pengetahuan) berarti perbedaan perlakuan terhadap salah satu jenis kelamin dengan memberikan pekerjaan jauh lebih banyak (berganda) dibandingkan dengan jenis kelamin lainnya. Dalam hal ini yang dimaksud adalah pekerjaan lebih banyak pada pihak perempuan yaitu melaksanakan kerja domestik mengurus rumah, anak, melayani suami serta harus bekerja di luar rumah membantu perekonomian keluarga.

Menurut Pujiati (1986) perempuan bekerja diluar rumah disebabkan faktor ekonomi. Hasil penelitian lain menemukan bahwa perempuan bekerja di luar rumah bukan semata-mata karena alasan faktor ekonomi keluarga yang sedemikian sulit, tetapi juga beberapa motivasi lain, seperti suami tidak bekerja/pendapatan kurang, ingin mencari uang sendiri, mengisi waktu luang, mencari pengalaman, ingin berperan serta dalam ekonomi keluarga dan adanaya keinginan mengaktualisasikan diri (menurut Novari, dkk (1991). Jadi tidak semata karena faktor ekonomi menyebabkan seorang perempuan bekerja hingga ia mengalami double burden.

Menurut Jockes (1985) dalam Nuril Huda (2008) bentuk struktur rumah tangga dimana perempuan mencari pekerjaan yang mendapatkan upah dapat dianalisis salah satunya dari teori gender yang menekankan bahwa perempuan yang bekerja dan juga melakukan tugas domestik di rumah merupakan satu kesatuan yang tak terpisahkan. Hal ini merupakan bagian integral dari keseluruhan sistem sosial. Kenyataannya masih banyak streotipe yang muncul di masyarakat bahwa perempuan adalah makhluk kelas rendah dibawah laki-laki dan penghasil sekunder dari pendapatan rumah tangga secara keseluruhan.

Realitanya kondisi ekonomi memang menjadi faktor yang sangat berpengaruh dalam kehidupan rumah tangga. Banyak kasus perceraian terjadi yang dipicu oleh masalah tidak tercukupinya kebutuhan hidup. Hal ini dibuktikan dari angka tertinggi perceraian pada pengadilan agama di salah satu kota besar di Indonesia tahun 2016 adalah karena faktor 
ekonomi (Octavia Devaluasia, 2017:108), dimana masing-masing pasangan tidak kuat menghadapi ujian ekonomi yang mendera rumah tangga mereka.

Pada hakekatnya status sosial ekonomi keluarga antara satu dengan yang lain berbeda, yang dapat dibagi menjadi tiga tingkatan yaitu tinggi, menengah dan rendah (Sutrisno Hadi, 2001). Dalam kehidupan bermasyarakat terdapat stratifikasi sosial yaitu golongan ekonomi tinggi, sedang dan rendah.

Keadaan ekonomi keluarga yang tinggi cenderung mampu menyekolahkan anaknya pada jenjang yang lebih tinggi. Sedangkan keadaan ekonomi keluarga yang rendah hanya mampu menyekolahkan anaknya pada jenjang yang rendah biasanya hanya sampai SD (Sekolah Dasar). Kriteria miskin dengan patokan indeks kebutuhan minimum energi 2.100 kalori per kapita/hari (kira kira 2000-2500 kalori per hari untuk laki laki dewasa). Bank Dunia mendefinisikan Kemiskinan absolute sebagai hidup dengan pendapatan dibawah USD $\$ 1 /$ hari dan kemiskinan menengah untuk pendapatan dibawah $\$ 2$ per hari.

Menteri sosial menyebutkan berdasarkan indikator BPS (Badan Pusat Statistik) garis kemiskinan yang diterapkannya adalah keluarga yang memilki penghasilan di bawah Rp 150.000 perbulan. Bahkan Bappenas yang sama mendasarkan pada indikator BPS (Badan Pusat Statistik) tahun 2005 batas kemiskinan keluarga adalah yang memiliki penghasilan di bawah Rp 180.000 perbulan. Untuk daerah perdesaan ditetapkan rumah tangga miskin jika pengeluarannya kurang dari $320 \mathrm{~kg}$ setara beras, miskin sekali jika pengeluaran kurang 240 $\mathrm{kg}$ setara beras, dan paling miskin jika pengeluaran kurang dari $180 \mathrm{~kg}$ setara beras per kapita per tahun. Untuk daerah perkotaan rumah tangga miskin, miskin sekali, dan paling miskin berturut-turut adalah pengeluaran rumah tangga sebesar 480, 360, dan $270 \mathrm{~kg}$ setara beras.

Tingkat kehidupan keluarga yang ekonomi rendah berbeda sekali dengan ekonomi keluarga yang tinggi. Jika keluarga yang berekonomi rendah akan mengalami kesulitan dalam memenuhi kebutuhannya sedangkan keluarga yang berekonomi tinggi akan mengalami kemudahan dalam memenuhi kebutuhannya.

Hal ini terjadi pada keluarga yang tinggal di kota tapi suami tidak memiliki pekerjaan tetap sehingga melakukan aktivitas memungut sampah yang dapat didaur ulang yang dikenal dengan sebutan pemulung. Fenomena ini menarik dilihat dari kehidupan perempuan pemulung muslim yang melakukan aktivitas memungut, memilih dan menjualkan sampah daur ulang, untuk membantu menafkahi keluarganya. Mereka tetap 
tabah menjalani kehidupan dan himpitan ekonomi tanpa harus bercerai dari suami yang belum mampu menafkahi kehidupan keluarga dengan mapan.

Pekerjaan ini tergolong pekerjaan yang dianggap "hina" dan tidak membutuhkan skill serta modal. Menurut Azhari (2009) pemulung adalah golongan sosial yang memiliki usaha mengumpulkan barang bekas. Mereka mengambil berbagai barang bekas, barang diambil dari jalan, tempat pembuangan sampah, pekarangan rumah penduduk, pasar, pertokoan, terminal, stasiun, bandara, tempat wisata, rumah ibadah, sekolah, kampus dan pemakaman.

Berdasarkan pra penelitian diketahui bahwa ada beberapa perempuan muslim pemulung di Kota Pekanbaru yang bertahan melakukan kegiatan mengumpulkan barang bekas dari masyarakat untuk dijual kepada pemasok untuk menambah dan memenuhi kebutuhan keluarga, mengalami ketidakadilan gender double burden ini. Mereka harus menjalankan tugas wajib yaitu tugas domestik di rumah sebagai ibu rumah tangga dan membesarkan anaknya. Pekerjaan memulung yang mereka lakukan berbanding terbalik dengan hasil yang diperoleh, namun kenyataannya mereka harus menjalaninya. Hal menarik dari ketabahan perempuan muslim yang bekerja sebagai pemulung ini menjadi alasan dilakukannya penelitian lebih lanjut.

Pertanyaan yang ingin dijawab dari penelitian ini adalah bagaimana bentuk beban ganda perempuan muslim yang bekerja sebagai pemulung ? Apa respon dan perspektif mereka tentang beban ganda tersebut? Jawaban terhadap pertanyaan penelitian ini menjadi isi dari artikel ini.

\section{METODE PENELITIAN}

Jenis penelitian ini adalah penelitian fenomenologis dengan pendekatan kualitatif. Penelitian dilakukan di Kota Pekanbaru. Subjek penelitian adalah 8 orang perempuan pemulung muslim sebagai informan primer, suami dan anak mereka sebagai informan sekunder.

Penelitian kualitatif mengharuskan peneliti berfungsi sebagai instrumen penelitian yang terjun langsung ke lapangan serta berusaha mengumpulkan informasi melalui pengamatan/observasi, dan wawancara mendalam. Data yang dikumpulkan selanjutnya dianalisis dengan langkah; koleksi data, reduksi, display dan terakhir dilakukan penarikan kesimpulan dan verivikasi data (Miles dah Huberman, 1984). 


\section{HASIL DAN DISKUSI}

\section{Bentuk double burden Perempuan Pemulung Muslim dalam Mendukung Perekonomian Keluarga}

Dari hasil wawancara mendalam dengan para perempuan pemulung muslim diperoleh gambaran bahwa mereka melakukan pekerjaan memulung setiap hari mulai jam 06 pagi sampai jam 10.00 pagi, disambung setelah solat zuhur bahkan sebagian masih melanjutkan pada malam hari. Mereka telah bangun sebelum azan subuh setiap harinya. Kegiatan domestik pagi hari diawali dengan membereskan pekerjaan rumah, menyiapkan makan keluarga sebelum berangkat.

Disela waktu istirahat, mereka juga harus mengerjakan pekerjaan rumah tangga seperti memasak, belanja keperluan dapur dan membersihkan rumah, bahkan mengantar dan menjemput anak dari sekolah. Waktu untuk istirahat yang mereka peroleh rata-rata 5-7 jam dalam sehari yang digunakan untuk membersihkan diri (mandi) dan tidur serta melakukan aktivitas ibadah.

Barang bekas yang diambil dalam kegiatan memulung berasal dari pembuangan sampah. Barang-barang tersebut yang masih layak dijual seperti gelas aqua, botol minuman, kardus, plastik (karah), besi tua, aluminium. Barang yang sudah terkumpul dijual ke pengepul kurang lebih Rp 200.000 sampai Rp 300.000 per minggu. Rata-rata perempuan pemulung mendapat penghasilan Rp 800.000 perbulannya. Uang yang diperoleh membantu membiayai kontrakan rumah, sekolah anak, biaya listrik, dan keperluan hidup sehari-hari.

Ternyata selain memulung, 4 dari 8 perempuan pemulung muslim memiliki pekerjaan lain, yaitu seperti: (1) membersihkan rumah kos-kosan yang ada didekat kediamannya, dengan penghasilan Rp. 200.000/bulan, (2) mengisi air aki di bengkel dengan penghasilan seribu per satu kotak air aki, (3) single parents yang memiliki 6 orang anak dan 12 cucu selain mengumpulkan barang bekas juga membuat kue yang dititipkan diwarungwarung dan kantin sekolah tempat anaknya bekerja.

Faktor yang menyebabkan mereka melakukan pekerjaan memulung adalah tidak terpenuhinya kebutuhan sehari-hari dari pekerjaan suami. Hal ini diungkapkan salah satu pemulung perempuan muslim dalam hasil wawancara sebagai berikut :

"Kami sudah menikah 20 tahun dan memiliki 5 orang anak, 4 laki-laki 1 perempuan. Mereka masih sangat membutuhkan biaya untuk sekolah. Saat itu, suami saya berhenti bekerja sebagai buruh dipabrik karena PHK besar-besaran. Awalnya dengan modal uang yang diberikan perusahaan tempat suami saya bekerja, kami dapat membuka usaha menjual makanan seperti lontong, pecal dan makanan kecil lainnya untuk sarapan. Waktu itu ekonomi keluarga kami masih lumayan. Namun hanya 
beberapa tahun, tempat kami berjualan digusur oleh pemilik tanah. Kami tidak diperbolehkan berjualan di sana. Suami saya sudah patah semangat dan tidak lagi mau bekerja yang terikat dengan orang lain. Ia berusaha mengumpulkan sampah yang dapat dijual ke penadah, sambil menerima pekerjaan yang ditawarkan orang padanya. Uang yang diberikannya ke pada saya setiap minggu hanya cukup untuk membeli kebutuhan harian bahkan kadang kurang. Sementara anak-anak yang bersekolah juga memerlukan biaya. Saya memutuskan untuk membantu suami, karena tidak ingin kondisi kami seperti ini saja. Sebenarnya jika ada modal, saya ingin berjualan makanan lagi, tapi modal itu tidak ada".

Berdasarkan gambaran ini dapat dilihat bahwa faktor ekonomi menjadi alasan utama perempuan pemulung melakukan pekerjaan tersebut. Hal ini sesuai dengan pendapat Pujiati (1986) perempuan bekerja diluar rumah disebabkan faktor ekonomi. Kenyataan bahwa keluarga perempuan pemulung muslim telah berupaya melakukan kegiatan lain sebelum memulung namun banyak mengalami kendala, dipahami mereka sebagai cobaan hidup. Hal menarik bahwa sang suami tidak ingin terikat bekerja dalam satu aturan yang dibuat atasan, dihargai saja oleh perempuan pemulung muslim. Ia meyakini bahwa rezeki yang diperoleh adalah atas usaha yang dilakukan. Konsep ini menjadikan rumah tangga mereka tidak sampai bercerai karena faktor kurangnya ekonomi. Sesungguhnya dalam ajaran Islam, apa yang diyakini manusia terkait dengan usaha maka Allah SWT akan mengabulkannya. Sebagaimana hadis dari Abu Hurairah, ra., Rasulluah bersabda, Allah berfirman, "Aku (Allah) sesuai dengan prasangka hamba pada-Ku. Keyakinan ini menjadikan keluarga pemulung, tetap mampu bertahan hidup dalam himpinan masalah ekonomi.

\section{Respon dan perspektif mereka tentang beban ganda}

Dari hasil wawancara dengan ke-8 wanita pemulung muslim tersebut diperoleh informasi bahwa mereka mengetahui beban mencari nafkah keluarga bukan hanya sebatas tanggung jawab suami. Mereka berinisiatif membantu suami sebisa mungkin, dan cara yang mudah dilakukan adalah dengan cara menjadi pemulung. Hal ini disebabkan oleh kondisi penghasilan suami tidak cukup, sementara kebutuhan rumah tangga sangat banyak.

Perempuan pemulung muslim yang posisinya sebagai istri sekaligus ibu turut membantu membiayai sekolah anak, bahkan ada perempuan pemulung muslim yang berstatus janda dengan usia yang sangat renta yaitu diatas 60 tahun harus menanggung biaya sekolah cucunya kerena cucunya telah menjadi anak yatim. Informasi dari 5 perempuan pemulung bahwa uang yang diperoleh dari memulung, mampu membiayai uang kontrakan 
rumah karena mereka tidak memiliki rumah sendiri. Hanya satu keluarga pemulung yang memiliki rumah sendiri walaupun membelinya secara cara kredit dengan uang angsuran Rp. 700.000 perbulannya.

Ketabahan mereka bertahan dengan kehidupan rumah tangga yang serba kekurangan dan rela menerima peran ganda tanpa menyalahkan suami hingga bercerai, didasari oleh keyakinan dan keimanan mereka pada Allah SWT. Hal ini terungkap dalam hasil wawancara dengan perempuan pemulung muslim sebagai berikut:

"Kami menerima dengan ikhlas, apapun yang terjadi dengan rumah tangga kami yang serba kekurangan ini. Tidak ada yang dapat disalahkan seperti suami yang tidak mampu banyak menafkahi keluarga. Allah SWT telah memberikan saya kesempatan untuk membantu suami dengan memulung. Bagi saya yang penting bisa kumpul bersama anak dan suami serta makan yang berasal dari uang halal bukan hasil curian".

Sikap tabah menerima kondisi perekonomian keluarga yang miskin bahkan berusaha membantu suami dengan menanggung beban ganda ini didukung oleh faktor barang bekas tersebut mudah ditemukan disekitar lingkungan masyarakat, seperti pada tempat pembuangan sampah, di sekitar jalan-jalan umum. Barang bekas dapat diperoleh dengan modal yang minim, bagi yang berjalan kaki cukup bermodal tenaga saja, tetapi sebagain naik angkutan umum seperti oplet untuk sampai ke tempat tujuan mencari barang bekas, dan ada yang menggunakan sepeda motor agar lokasi pencarian barang lebih luas. Mereka hanya menggunakan alat-alat yang sederhana seperti karung, atau alat pengait barang bekas sehingga tidak terlalu berat dalam mengerjakannya.

Namun dibalik itu ada kekhawatiran yang dirasakan oleh perempuan pemulung terutama karena sebagian pemulung pada usia tua renta. Mereka tidak bisa berjalan terlalu jauh memungut sampah. Bagi pemulung yang tidak memiliki kendaraan sendiri maka lokasi mencarian barang bekas terbatas pada satu daerah saja, sehingga jumlah yang ditemukan minim, dan akan berdampak pada penghasilan yang minim juga. Selain itu pihak yang mencari barang bukan hanya pemulung perempuan muslim, akan tetapi sudah banyak seperti kaum pria yang ikut mencari barang bekas, sehingga sudah banyak saingan dalam menemukan barang bekas tersebut.

Tantangan lain yang mereka dapatkan adalah jika melewati perumahan masyarakat, ada sebagaian warga yang melarang pemulung untuk mendekat atau bahkan ada yang mengusir karena sudah beranggapan akan mengganggu atau dikhatirkan ada niat mencuri. Hal ini menjadi salah satu faktor yang menghambat dalam pelaksanaan pekerjaan mereka sebagai pemulung. 
Namun pada hakikatnya pekerjaan mereka ini membantu pemerintah dalam mengurangi sampah dan memanfaatkan barang bekas untuk dapat didaur ulang. Keberadaan mereka disatu sisi dapat dianggap sebagai pahlawan lingkungan.

Double Burden atau beban ganda adalah dua peran atau lebih yang dijalankan dalam waktu yang bersamaan yaitu sebagai istri bagi suaminya, ibu bagi anak-anaknya, dan peran sebagai perempuan yang bekerja di luar rumah. Peran ganda ini dijalani bersamaan dengan peran tradisional kaum perempuan sebagai istri dan ibu dalam keluarga, seperti menjadi mitra suami dalam membina rumah tangga, menyediakan kebutuhan rumah tangga, serta mengasuh dan mendidik anak-anak.

Mansur Faqih (1996) menjelaskan bahwa sejak abad ke-21 perempuan dituntut untuk memiliki sikap mandiri, disamping suatu kebebasan untuk mengembangkan dirinya sebagai manusia 15 yang sesuai dengan bakat yang telah dimilikinya. Profil wanita Indonesia saat ini dapat digambarkan sebagai manusia yang harus hidup dalam situasi dilematis. Disatu sisi ia dituntut untuk berperan dalam semua sektor, tetapi disisi lain muncullah tuntutan agar tidak melupakan kodrat mereka sebagai wanita. Dalam keluarga konvensional, suami bertugas mencari nafkah sedangkan istri bertugas mengurus rumah tangga, tetapi dengan tumbuhnya kesempatan bagi wanita bersuami untuk bekerja, maka pola kekeluargaan segera berubah dan muncul apa yang disebut sebagai dualisme karir. Nilai-nilai tradisional yang ada dalam masyarakat memang dapat menjadi tekanan sosial.

Meningkatnya peran wanita sebagai pencari nafkah keluarga maka bertambah pula masalah-masalah yang timbul. Kedua peran tersebut sama-sama membutuhkan waktu, tenaga, dan, perhatian, sehingga kalau peran yang satu dilakukan dengan baik, maka yang lain terabaikan sehigga timbullah konflik peran. Seorang istri yang menjadi ibu rumah tangga dan pencari nafkah (berperan ganda) harus memenuhi tugas dan kewajibannya sebagai ibu rumah tangga dan diharapkan dapat menjalankan peranannya sebagai seorang istri dan pencari nafkah.

Salah satu jenis pekerjaan yang dilakukan oleh perempuan dalam konteks pencari nafkah adalah memulung. Pemulung menurut Simardjoko, Bambang (2003) adalah orangorang yang melakukan kegiatan mengumpulkan, memungut, dan memilih sampah atau barang bekas yang dapat dimanfaatkan atau barang yang dapat diolah lagi untuk dijual. Menurut Jhones dalam Simardjoko (2003), pemulung adalah orang yang pekerjaannya memungut dan mengumpulkan barang-barang bekas dari tempat sampah kota. Barangbarang yang dikumpulkan berupa plastik, kertas, kardus, kaleng, pecahan kaca, besi tua, dan 
barang bekas lainnya. Defenisi lain menjelaskan pemulung adalah cara mencari nafkah dengan jalan mencari dan memungut serta memanfaatkan barang-barang bekas untuk kemudian menjualnya kepada pengusaha yang akan mengolahnya kembali menjadi barang komoditi baru atau lain (Team Depdikbud, 1993).

Dari beberapa definisi mengenai pemulung dapat disimpulkan bahwa pemulung adalah orang yang bekerja dengan cara atau kegiatan yang mengumpulkan segala jenis sampah atau limbah yang masih bisa dimanfaatkan dengan tujuan untuk memperoleh pendapatan demi pemenuhan kebutuhan hidupnya. Rahardian (2003) menjelaskan dalam penelitiannya tentang cara-cara pemulung untuk bertahan hidup dalam menghadapi masalah keuangan yaitu dengan cara mengatur pola konsumsi, menjalin relasi sosial, dan mengikuti arisan. Pola konsumsi yang dilakukan pemulung dengan upaya yang luar biasa. Pertama, pola pengeluaran yaitu dengan cara presentase pengeluaran rumah tangga dengan diarahkan pada kebutuhan pangan. Keluarga pemulung yang lebih mendahulukan masalah pangan dari pada masalah pendidikan. Kedua, porsi konsumsi makanan dengan pangan yang tersedia yaitu makan 1-2x sehari bisa makan satu hari sekali pada waktu siang saja dan makan dua kali sehari siang dan malam.

Rahardian (2003) menjelaskan bentuk penguatan jaringan sosial yaitu menjalin relasi sosial antar pemulung, keluarga dan masyarakat. Hubungan yang terbentuk adalah hubungan Expressive-instrumental continuum yaitu hubungan yang terbentuk bukan hanya untuk mendapakan rasa aman, cinta, penerimaan, pertemanan, dan rasa bermanfaat antara pemulung yang satu dengan yang lainnya tetapi juga untuk mendapatkan bantuan dari pemulung lainnya. Ketika seorang pemulung mengalami kesulitan mereka tidak hanya menginginkan pemulung lain mendengarkan keluhannya tetapi pemulung tersebut juga mengharapkan bantuan dari pemulung lain. Kesulitan pemulung biasanya pada masalah keuangan. Hubungan tolong menolong dibangun pemulung tanpa pamrih dengan artian pemulung dalam mempertahankan hidupnya dengan menjalin hubungan kerjasama yang saling menguntungkan dengan berbagai pihak bersama-sama di tempat kerja. Mereka juga mengikuti arisan, uang arisan yang diperoleh digunakan untuk membeli barang-barang yang bernilai jual (TV, Radio, dll) sehingga pada waktu butuh mereka akan menggadaikan atau menjual barang.

Berkaitan dengan peran perempuan dalam bekerja dan melakukan aktivitas pemulung perlu kita pahami bahwa beberapa anggapan yang salah tentang keberadaan perempuan bekerja masih ada di masyarakat. Suhandjati dan Sofwan (2000) menyatakan 
adanya anggapan sebagian masyarakat, bahwa perempuan hanya sebagai pembantu dan pengatur bukan sebagai salah satu pemimpin di dalam rumah tangga, yang fungsinya sebagai pendukung suami, yang bertugas untuk memperhatikan suami bukan subyek yang perlu mendapat perhatian. Perempuan hanya dianggap sebagai subyek yang pekerjaannya sebagai konsumen penghabis gaji atau pendapatan yang diperoleh suami. Anggapan seperti itu tidak dapat dibenarkan, karena disadari perempuan juga berkemampuan untuk mencari nafkah atau gaji, untuk mendapatkan alternative pendapatan dan berprestasi.

Istri di dalam rumah tangga pada umumnya bertugas mengurus rumah tangga seperti memasak membersihkan rumah, membuat masakan untuk keluarga. Peran domestic dipahami sebagai peran yang berkaitan dengan urusan rumah tangga, seperti menangani pekerjaan dapur, yang berkaitan dengan urusan rumah tangga, mengasuh anak, menyediakan kebutuhan sekolah, menyiapkan makanan untuk keluarga. Peran domestik identik dengan pekerjaan istri yang berperan dalam wilayah domestik yang bertanggungjawab untuk menyelesaikan pekerjaan rumah tangga. Hurt dan Horton dalam Hendi (2001) menjelaskan tentang fungsi fungsi keluarga yaitu: Fungsi biologis, fungsi sosialisasi anak, fungsi afeksi, fungsi edukasi, fungsi religius, fungsi proteksi, fungsi ekonomi, dan fungsi rekreasi.

Menurut Budiman (1983) perbedaan posisi antara ayah dan ibu dalam keluarga pada dasarnya disebabkan oleh faktor biologis. Secara badaniah, perempuan berbeda dengan lakilaki. Alat kelamin perempuan berbeda dengan alat kelamin laki-laki, suara perempuan lebih halus, perempuan melahirkan anak dan sebagainya. Selain itu secara psikologis, laki-laki akan lebih rasional, lebih aktif, lebih agresif. Sedangkan secara psikologis perempuan lebih emosional dan lebih pasif.

Adapun perspektif Ajaran Islam kewajiban seorang isteri terhadap suaminya dalam terkait dengan masalah ekonomi keluarga menurut Nurnasrina (2013) yaitu (1) Tidak menginfakkan sesuatu hartanya kecuali ada izin dari suami, (2) Mensyukuri pemberian suami, selalu merasa cukup dan melayani suami dengan baik (3)Tidak berbuat sesuatu yang dapat menyakiti dan tidak disukai oleh suami (4) Taat kepada suami (5) Menjaga kehormatan dirinya, menjaga putra putrinya juga harta suaminya ketika si suami sedang tidak di rumah. Wendi Zarman (2017:21) menjelaskan di dalam Islam, mencari nafkah adalah kewajiban suami, bukan istri. Namun, ada kalanya memang penghasilan suami tidak mencukupi untuk membiayai pengeluaran rumah tangga. Bila memang keadaan ekonomi rumah tangga atau pertimbangan rasional lain mengharuskannya untuk bekerja, maka pilihan bekerja itu dapatlah dimaklumi. Demikian juga jika dipundaknya terdapat fardhu 
kifayah yang harus ditunaikan, yaitu ketika harus ada kaum wanita yang mengambil peranperan tertentu demi kemaslahatan masyarakat.

\section{KESIMPULAN DAN REKOMENDASI}

Menjadi perempuan adalah satu kodrat yang Tuhan berikan yang tidak bisa dipilih saat individu lahir kemuka bumi. Tidak seorangpun menafikan kenyataan bahwa pria dan wanita dikaruniai potensi yang berbeda-beda oleh Allah SWT. Perbedaan inilah yang kemudian menumbuhkan peran dan tanggungjawab yang berbeda pula. Setelah ia dewasa dan menikah serta dikarunia anak maka menurut Wendi Zarman (2017:22) sejak itu ia dibebani amanah sebagai istri dan ibu.

Kenyataannya perempuan harus melakukan beban dan peran ganda, karena suami tidak mencukupi dalam membiayai kebutuhan rumah tangga. Perempuan yang bekerja diluar rumah sudah dimaklumi namun tetap harus menjalankan kewajiban domestik mengurus rumah tangga.

Beban ganda yang diemban oleh perempuan pemulung muslim menjadi satu bentuk ketabahan yang mereka rasakan. Ternyata keyakinan dan keimanan menjadi benteng mereka tabah menjalani kehidupan dengan bebab ganda tersebut.

Kedepan diharapkan agar selain menjual barang bekas mereka juga belajar untuk mengolah atau mendaur ulang sampah agar lebih bernilai ekonomis yang lebih tinggi. Diharapkan juga pemerintah memberikan perhatian khusus untuk pemberdayaan perempuan pemulung ini, dengan melakukan penyuluhan dan pelatihan terhadap perempuan, agar kelak mereka dapat berkerja ditempat yang lebih baik.

\section{DAFTAR PUSTAKA}

Aep Saepulloh Darusmanwiati, 2005. Hak dan Kewajiban Suami Istri (makalah). Pojok Mesjid al-Azhar Kairo.

Djam'an Sat ori dan Aan Komariah, 2014. Metodologi Penelitian Kualitatif Bandung: Alfabeta. Hamid Patilima. 2011. Metode Penelitian Kualitatif. Bandung: Alfabeta.

Nurnasrina, 2013. Ekonomi Islam Sarana Dalam Mewujudkan Ekonomi Masyarakat Madani jurnal penelitian). Pekanbaru.

Simardjoko, Bambang. 2003. Profil Pemulung perempuan di Surakarta. Laporan Penelitian. Universitas Muhammadiyah Surakarta.

Sutrisno, Hadi. 2001. Metodologi Research. Yogyakarta: Andi. 
Suharsimi Arikunto. 2002. Prosedur Penelitian Suatu Pendekatan Praktek. Jakarta: Rineka Cipta. Team Depdikbud, 1993. Kamus Besar Bahasa Indonesia.Jakarta: Yayasan Obor Indonesia.

Tohirin, 2012, Metode Penelitian Kualitatif dalam Pendidikan dan Bimbingan Konseling Jakarta: Rajawali Pers.

Mansur Faqih. 1996. Analisis Gender dan Transformasi sosial. Yogyakarta:Pustaka Pelajar, hal.8

Denrich Suryadi, 2004. Gambaran Konflik Emosional Dalam Menentukan Prioritas Peran Ganda. Jurnal Ilmiah Psikologi Arkhe 1 (Januari, 2004) hal.12 24

Budiman, Arif, 1983. Pembagian Kerja Secara Sexual, Suatu Pembahasan Sosiologis Tentang Peran Perempuan Didalam Masyarakat. Jakarta: PT. Gramedia. 